\title{
Antioxidant and Antimicrobial Activities of Pogostemon cablin (Blanco) Benth.
}

\author{
Bhanuz Dechayont, Pimnapa Ruamdee, Sukrita Poonnaimuang, \\ Khwanchanok Mokmued, and Jitpisute Chunthorng-Orn \\ Department of Applied Thai Traditional Medicine, Faculty of Medicine, Thammasat University, Pathum Thani, Thailand \\ Correspondence should be addressed to Bhanuz Dechayont; nuzz@hotmail.com
}

Received 30 November 2016; Revised 21 February 2017; Accepted 8 March 2017; Published 29 March 2017

Academic Editor: Maria R. Ercolano

Copyright (C) 2017 Bhanuz Dechayont et al. This is an open access article distributed under the Creative Commons Attribution License, which permits unrestricted use, distribution, and reproduction in any medium, provided the original work is properly cited.

Pogostemon cablin (Lamiaceae) has been widely used in traditional medicine. In this study, the antioxidant and antimicrobial activities of leaves from $P$. cablin extracts were investigated. The water extracts had the highest total phenolic content $116.88 \pm 0.48 \mathrm{mg}$ gallic acid equivalent/g of dry plant extract. Nevertheless, high levels of total flavonoid content were found in ethanolic extracts $280.12 \pm 2.04 \mathrm{mg}$ quercetin equivalent/g of dry plant extract. The highest antioxidant activities were found for the ethanolic extract $\left(\mathrm{IC}_{50}=18 \pm 0.90,20 \pm 0.24 \mu \mathrm{g} / \mathrm{mL}\right)$ by DPPH and ABTS scavenging assays, respectively. Both extracts showed moderate inhibition of superoxide inhibition $\left(\mathrm{O}_{2}{ }^{--}\right)$and nitric oxide (NO) production in concentration-dependent manner. Antibacterial activity was calculated by disk diffusion, minimum inhibitory concentration (MIC), and minimum bacterial concentration (MBC). The ethanolic extract had the greatest activity against methicillin resistant Staphylococcus aureus, methicillin sensitive $S$. aureus, and Streptococcus pyogenes with zone diameters of $11.67 \pm 1.53,10.33 \pm 2.52$, and $10.33 \pm 1.15 \mathrm{~mm}$, respectively. The corresponding MIC and MBCs were 5, 0.625 , and $0.039 \mathrm{mg} / \mathrm{mL}$. P. cablin extracts contain antioxidant and antibacterial properties that should be exploited for possible clinical application.

\section{Introduction}

Fever is the regulated rise in body temperature above the normal range; it has been recognized as a sign of infection since ancient times [1]. The most common cause of fever is bacterial infections [2] which are also one of the most common causes of the inflammation response [3]. Acute inflammation is characterized by increased blood flow and vascular permeability along with the accumulation of fluid, leukocytes, and inflammatory mediators such as cytokines [4]. Inflammation leads to the increased expression of nitric oxide (NO) which influences many aspects of the inflammatory cascade and may play a critical role in the pathophysiology of acute and chronic inflammatory diseases [5]. High concentrations of NO rapidly react with superoxide radical $\left(\mathrm{O}_{2}{ }^{--}\right)$to form peroxynitrite $\left(\mathrm{ONOO}^{-}\right)$, a highly reactive and toxic reactive nitrogen species (RNS). Indeed, a combination of reactive oxygen species (ROS) and NO production has been implicated in the pathogenesis of atherosclerosis, cancer, cardiovascular, and neurological diseases [6]. Therefore, inhibition of ROS and NO is a potential way to reduce oxidative stress and subsequent inflammation as well as prevent these chronic diseases in the future. However, currently used antimicrobials are failing to bring an end to many bacterial infections because of drug resistance and some antioxidants like butylated hydroxytoluene (BHT) cause carcinogen [7]. For this reason research is ongoing for natural antioxidant and antimicrobial activities.

Pogostemon cablin belongs to the family Lamiaceae and grows wild in Southeast Asia [8]. This plant has been widely used in traditional medicinal practice in Southeast Asia. In Thai medical scripture, the whole plant is used as a component herb in ailments and approximately 27 formulae are reported. The most common method of preparation is decoction and maceration with whisky for 4 formulae. Typically, folk medicine used $P$. cablin to reduce fevers and chronic fatigue, restore function, and improve the digestion [9]. 
There are reports detailing individual properties of this plant's essential oils such as antimicrobial $[10,11]$, antioxidant [12], analgesic [13], anti-inflammatory [14], antimutagenic [15], antithrombotic [16], antiemetic [17], and cytotoxic activities $[18,19]$. However, there are no reports which have studied the relationship between the antimicrobial and antioxidant activities of leaf extracts by using traditional extraction methods.

\section{Material and Methods}

The leaves of Pogostemon cablin were collected in March 2016 in Ratchaburi, Thailand. The leaves were dried at $45^{\circ} \mathrm{C}$ for 12 hours (h) and then underwent maceration and decoction to obtain the extracts.

\subsection{Preparation of Extracts}

2.1.1. Maceration Method. $30 \mathrm{~g}$ of dry powder leaf was soaked in $500 \mathrm{~mL}$ of $95 \%$ ethanol and allowed to stand at room temperature for 74 hours in a well-lit room. The extract was stirred every 24 hours by using a sterile glass rod and filtered through a Whatman No. 1 filter paper and was concentrated by evaporator to obtain the ethanolic extracts. Then, the extract was stored at $-20^{\circ} \mathrm{C}$.

2.1.2. Decoction Method. $30 \mathrm{~g}$ of dry powder leaf was boiled in $500 \mathrm{~mL}$ of distilled water for 15 minutes. Then, the concentrated extract was filtered and dried by lyophilization to obtain the aqueous extract. Then, the extract was stored at $-20^{\circ} \mathrm{C}$.

\subsection{Determination of Bioactive Compounds Content}

2.2.1. Determination of Total Phenolics Content [20]. Total phenolic contents in the extracts were determined by the modified Folin-Ciocalteu method using microplate readers. First, $20 \mu \mathrm{L}$ of the extract was mixed with $100 \mu \mathrm{L}$ FolinCiocalteu's reagent in 96-well microplate. After waiting for 5 minutes, $80 \mu \mathrm{L}$ of sodium carbonate was added, and the plate was allowed to stand for 30 minutes. Absorbance values of samples were measured at $765 \mathrm{~nm}$. Gallic acid (GA) was used as the standard phenolic substance to compare with extracts. Total phenolic content was expressed as milligram of gallic acid equivalent per gram of dry weight of each extract (mg GAE/g). All measurements were performed in triplicate.

\subsubsection{Determination of Total Flavonoid Content [21]. Total} flavonoid content was performed by the aluminum chloride colorimetric method. $500 \mu \mathrm{L}$ of each extract was mixed with $75 \mu \mathrm{L}$ of $5 \%(\mathrm{w} / \mathrm{v})$ sodium nitrite after which $150 \mu \mathrm{L}$ of $10 \%$ (w/v) aluminum chloride complex had been added and left for 5 minutes $(\mathrm{m}) .500 \mu \mathrm{L}$ of $1 \mathrm{M}$ sodium hydroxide was added, and the volume was supplemented to $1500 \mu \mathrm{L}$ with distilled water. Then, the reaction was incubated for $30 \mathrm{~m}$ at room temperature $\left(25^{\circ} \mathrm{C}\right)$. The absorbance was measured at $510 \mathrm{~nm}$. Total flavonoid content was expressed as milligram of quercetin equivalents per gram of dry weight of each extract (mg QE/g).
2.3. Determination of Antioxidant Activity Using the DPPH Radical Scavenging Assay [22]. 2,2-Diphenyl-1-picrylhydra$\mathrm{zyl}(\mathrm{DPPH})$ is a stable free radial. The assay is based on the reduction of DPPH with antioxidant. In brief, $100 \mu \mathrm{L}$ of $6 \times 10^{-5} \mathrm{M}$ DPPH solution in absolute ethanol was mixed with $100 \mu \mathrm{L}$ of different concentrations of the extract and incubated for $30 \mathrm{~m}$ in a dark at room temperature. The absorbance was measured at $520 \mathrm{~nm}$ using microplate readers. Trolox and BHT were used as positive controls. Initially, $\mathrm{DPPH} \mathrm{IC}_{50}$ was determined and defined as the antioxidant concentration needed to reduce DPPH activity by $50 \%$, a parameter widely used to measure the antioxidant activity. The antioxidant scavenging activity was calculated as a percentage inhibition in the formulae below:

The Percentage of Inhibition

$$
=\left(\frac{\text { Abs. Control }- \text { Abs. Sample }}{\text { Abs. Control }}\right) \times 100 \text {. }
$$

2.4. Determination of Antioxidant Activity Using ABTS Radical Cation Decolorization Assay [23]. The ABTS [2,2' -azinobis-(3-ethylbenzothiazoline-6-sulfonic acid)] assay has two steps, the preparation of ABTS radical solution followed by the discoloration assay. $\mathrm{ABTS}^{\bullet+}$ radical solution is prepared by mixing $7 \mathrm{mM}$ ABTS solution with $2.45 \mathrm{mM}$ potassium persulfate. The reaction mixture was allowed to stand in the dark at room temperature for 12-16 hours to complete radical generation. Then, the ABTS radical solution was diluted with deionized water to reach an absorbance of $0.68-0.72$ at $734 \mathrm{~nm}$ before being used. The discoloration assay was assessed by mixing $180 \mu \mathrm{L}$ of ABTS radical solution with $20 \mu \mathrm{L}$ of various dilutions of each extract in 96-well microplates. The reaction mixture was allowed to stand for 6 minutes, and the absorbance was measured at $734 \mathrm{~nm}$ by using a microplate reader. The scavenging activity of extracts against ABTS radicals was calculated by the percentage inhibition of scavenging activity using the formula below and expressed as $\mathrm{IC}_{50}(\mu \mathrm{g} / \mathrm{mL})$.

$$
\begin{aligned}
& \text { The Percentage of Inhibition } \\
& =\left(\frac{\text { Abs. Control }- \text { Abs. Sample }}{\text { Abs. Control }}\right) .
\end{aligned}
$$

2.5. Determination of Nitric Oxide Production Using the Griess Reaction Assay [24]. Lipopolysaccharide (LPS) is inducible nitric oxide synthase (iNOS) which is the specific enzyme for synthesizing NO from L-arginine. In this assay, RAW 264.7 cells were seeded at $1 \times 10^{5}$ cells/well in 96-well microplates. After that, the medium containing $5 \mathrm{ng} / \mathrm{mL}$ lipopolysaccharide (LPS) and the extract at various concentrations were incubated for 48 hours at $37^{\circ} \mathrm{C}$ in a humidified atmosphere containing $5 \% \mathrm{CO}_{2}$. NO production was determined by measuring the accumulation of nitrite $\left(\mathrm{NO}_{2}{ }^{-}\right)$in the culture supernatant using the Griess reagent at $570 \mathrm{~nm}$. The percent 
inhibition of the extract at each concentration was calculated by the formula below:

The Percentage of Inhibition

$$
=\frac{(A c-A b)-(A s-A b)}{(A c-A b)} \times 100 .
$$

Ac and As are the absorbance of a mixture stimulated with LPS. $\mathrm{Ab}$ is the absorbance of a mixture nonstimulated with LPS.

The cytotoxic effect of the extract in RAW 264.7 cells was performed using the MTT assay. Briefly, MTT solution had been added to the cells and left for 4 hours. Then the medium was removed, and isopropanol containing $0.04 \mathrm{M}$ $\mathrm{HCl}$ was added to dissolve the formazan product in these cells. The absorbance of formazan solution was measured with a microplate reader at $570 \mathrm{~nm}$.

2.6. Determination of Superoxide Production Using Nitroblue Tetrazolium (NBT) Dye Reduction Assay [25]. HL-60 cells had been incubated for 6 days in PRMI 1640 medium supplement with $10 \%$ heated fetal bovine serum containing $1.3 \%$ DMSO. Intracellular superoxide formation was quantified by the NBT reduction assay. Briefly, $1 \times 10^{6}$ differentiated HL60 cells were dissolved in $200 \mu \mathrm{L}$ of Hank's Buffered Salt Solution (HBSS) to which various concentrations of each extract were added. The mixture was incubated at $37^{\circ} \mathrm{C}$ in $5 \% \mathrm{CO}_{2}$ for 15 minutes after which $250 \mathrm{ng} / \mathrm{mL}$ of phorbol12-myristate-13-acetate (PMA) and $1.25 \mathrm{mg} / \mathrm{mL}$ NBT were added and incubated for $60 \mathrm{~min}$. Finally, $2 \mathrm{~mL}$ of $1 \mathrm{M} \mathrm{HCl}$ was added to the reaction mixture. After centrifugation at $12,000 \times \mathrm{g}$ for 10 minutes, DMSO was added to dissolve the resulting formazan by using sonication. The absorbance was measured with a microplate reader at $560 \mathrm{~nm}$. The percent inhibition of each concentration was calculated by using the equation below:

The Percentage of Inhibition

$$
=\frac{(A c-A b)-(A s-A b)}{(A c-A b)} \times 100 .
$$

Ac and As are the absorbance of a mixture stimulated with PMA. Ab is the absorbance of a mixture nonstimulated with PMA.

The cytotoxic effect of extracts on HL-60 cells was assessed with the MTT assay. Briefly, the cells had been immersed in MTT solution for 4 hours. Following the centrifugation for 7 minutes, the mixture was dissolved with DMSO. The absorbance of formazan solution was measured with a microplate reader at $570 \mathrm{~nm}$.

\subsection{Evaluation of the Antimicrobial Activity}

2.7.1. Microbial Strains. Cultures of the following microorganisms were used in the study: (i) Staphylococcus aureus ATCC 25923 methicillin-susceptible, (ii) methicillin resistant Staphylococcus aureus (MRSA) ATCC 20651, (iii) Streptococcus pyogenes ATCC 19615, (iv) Pseudomonas aeruginosa ATCC 9097, and (v) Candida albicans ATCC 90028.
2.7.2. Disk Diffusion Method [26]. Disk diffusion was carried out with Mueller-Hinton agar (MHA) for S. aureus, MRSA, and $P$. aeruginosa, MHA with 5\% sheep blood for S. pyogenes, and Sabouraud Dextrose agar (SDA) for C. albicans. The colonies were suspended to a $0.5 \mathrm{McF}$ arland standard. $10 \mu \mathrm{L}$ of the extracts was added at concentration of $500 \mu \mathrm{g} / \mathrm{mL}$ to paper discs (6 mm in diameter). Positive controls in this study were Gentamicin and Amphotericin B $(1 \mathrm{mg} / \mathrm{mL})$. These plates had been incubated at $37^{\circ} \mathrm{C}$ for 24 hours for the bacteria and at $37^{\circ} \mathrm{C}$ for $48 \mathrm{~h}$ for the Candida. The zone of inhibition was calculated by measuring the diameter of the inhibition zone. Three different fixed directions were taken in triplicate, and the mean value was calculated.

2.7.3. Determination of Minimum Inhibitory Concentration (MIC) [27]. The MIC of the extracts was determined according to the microbroth dilution technique. In brief, the cultures were inoculated equivalent to a $0.5 \mathrm{McFarland}$ Standard in Mueller-Hinton broth (MHB). The cultures were diluted to $1 / 200$. The plant extracts were diluted by using double fold serial dilution in $\mathrm{MHB}$. Then $50 \mu \mathrm{L}$ of each culture and extract was mixed to a sterile 96 -well and incubated at $37^{\circ} \mathrm{C}$ for 24 hours for the bacteria and $37^{\circ} \mathrm{C}$ for 48 hours for the Candida. After that, resazurin $10 \mu \mathrm{L}$ was added in each well and incubated for 2 hrs. The color change was then assessed visually. The growth was indicated by no color change from purple to pink as the MIC value.

2.7.4. Determination of Minimum Bactericidal Concentration $(M B C)$ [28]. The minimum bactericidal concentration (MBC) is defined as the lowest concentration of an antimicrobial agent needed to kill the initial inocula. The MBC was determined by first selecting the well that showed no growth during the MIC determination. $10 \mu \mathrm{L}$ of each tube was subcultured onto agar plates and incubated for $37^{\circ} \mathrm{C}$ for 24 hours for the bacteria and at $37^{\circ} \mathrm{C}$ for 48 hours for the Candida.

2.8. Statistical Analysis. All experiments were carried out in triplicate and presented as means \pm SEM (standard error of the mean). A dose-response curve was obtained by plotting the percent inhibition values versus extract concentrations, and the $\mathrm{IC}_{50}$ values $(\mu \mathrm{g} / \mathrm{mL})$ were determined by cubic spline interpolation using GraphPad Prism (version 4.3).

\section{Results and Discussion}

The yields of water and ethanolic extracts were, respectively, $12.70 \%$ and $7.47 \% \mathrm{w} / \mathrm{w}$ in terms of dried starting material. In case of $P$. cablin, the extract yield increased with the temperature and polarity. The results of this study are in agreement with the extraction yields of some medicinal plants.

The total phenolic content was expressed as mg gallic acid per gram of dry plant extract (mg GAE/g). The highest total phenolic content was in the water extract (Table 1). These results indicate that increasing the temperature, polarity index (PI), and solubility of phenolic compounds in the extraction solvents enhance the content of phenols [29]. 
TABLE 1: Percent yield, antioxidant activity, and total phenolic and flavonoid contents of Pogostemon cablin leaves extracts $(n=3)$.

\begin{tabular}{|c|c|c|c|c|c|c|}
\hline \multirow[b]{2}{*}{ Methods } & \multirow[b]{2}{*}{ Extract } & \multirow[b]{2}{*}{ \% Yield } & \multicolumn{2}{|c|}{ Antioxidant activity $\left(\mathrm{IC}_{50} \mu \mathrm{g} / \mathrm{mL}\right)$} & \multirow{2}{*}{$\begin{array}{c}\text { Total phenolic } \\
\text { content (mg GAE/g) }\end{array}$} & \multirow{2}{*}{$\begin{array}{c}\text { Total flavonoid } \\
\text { content (mg QE/g) }\end{array}$} \\
\hline & & & $\begin{array}{c}\text { DPPH radical } \\
\text { scavenging assay }\end{array}$ & $\begin{array}{l}\text { ABTS radical cation } \\
\text { decolorization assay }\end{array}$ & & \\
\hline Decoction & Water & 12.70 & $60 \pm 1.18$ & $33 \pm 1.80$ & $116.88 \pm 0.48$ & $221.38 \pm 0.96$ \\
\hline \multirow[t]{3}{*}{ Maceration } & Ethanol & 7.47 & $18 \pm 0.90$ & $20 \pm 0.24$ & $99.59 \pm 0.54$ & $280.12 \pm 2.04$ \\
\hline & BHT & & $14 \pm 0.90$ & $4 \pm 0.90$ & - & - \\
\hline & Trolox & & $5 \pm 0.90$ & $3 \pm 0.90$ & - & - \\
\hline
\end{tabular}

TABLE 2: Cell based assay results of nitric oxide formation and superoxide production of Pogostemon cablin leaves extracts $(n=3)$.

\begin{tabular}{lcccc}
\hline \multirow{2}{*}{ Extract } & \multicolumn{2}{c}{ Nitric oxide inhibition } & \multicolumn{2}{c}{ Superoxide inhibition } \\
& $\left(\mathrm{IC}_{50} \mu \mathrm{g} / \mathrm{mL}\right)$ & \% Cell survival & $\left(\mathrm{IC}_{50} \mu \mathrm{g} / \mathrm{mL}\right)$ & \% Cell survival \\
\hline Water & $>200$ & $>70$ & $195.98 \pm 1.00$ & $>70$ \\
Ethanol & $144 \pm 4.90$ & $>70$ & $108 \pm 1.10$ & $>70$ \\
\hline
\end{tabular}

The solubility of polyphenols was observed to depend mainly on the presence and position of the hydroxyl groups and the molecular sizes and the lengths of constituent hydrocarbon chains [30].

The total flavonoid content was expressed as mg quercetin equivalents per gram of dry plant extract (mg QE/g). According to the results, the effective solvent used to extract flavonoid content appeared on ethanol solvent (Table 1). This may indicate that sequential extraction using ethanol solvent is the most appropriate to use for extractability of flavonoid content from P. cablin [31].

The DPPH radical scavenging activity is presented in Table 1. Compared to the water extract, the ethanolic extract had approximately a threefold increase in DPPH radical scavenging activity with $\mathrm{IC}_{50}=18 \pm 0.90 \mu \mathrm{g} / \mathrm{mL}$ and had $\sim 1.5-$ fold higher antioxidant activity with $\mathrm{IC}_{50}=20 \pm 0.24 \mu \mathrm{g} / \mathrm{mL}$ in the ABTS radical cation decolorization antioxidant assay. These results, which are consistent with those of others [3235], suggest that flavonoids have intrinsically high antioxidant properties and provide most of the antioxidant activity of leaf extracts. The result found flavonoid content which showed positive correlations with the antioxidant activity. Flavonoids, including flavones, flavanols, and condensed tannins, are plant secondary metabolites and their antioxidant activities depend on the presence of free $\mathrm{OH}$ groups, especially 3$\mathrm{OH}$ [36], the total number of hydroxyl groups, and the substitution of functional groups on their nuclear structures [37].

In cell-based bioassays, the results showed that ethanolic extract was the most active against $\mathrm{NO}$ and $\mathrm{O}_{2}{ }^{--}$in a dosedependent manner $\left(\mathrm{IC}_{50}=144 \pm 4.90\right.$ and $\left.108 \pm 1.10 \mu \mathrm{g} / \mathrm{mL}\right)$ (Table 2). To ensure that the extracts were not cytotoxic, MTT assay was used to measure cell viability. All the extracts showed more than $70 \%$ of the cell viability. The ethanolic extract had higher nitric oxide scavenging and antioxidant activities compared to the water extract but the $\mathrm{IC}_{50}$ values were relatively high and the ethanolic to water ratios lower compared to the results of the DPPH and ABTS assays. Those experimental results have demonstrated that the ethanolic extract exhibited $\mathrm{O}_{2}{ }^{--}$and NO. Interestingly, the results of this study imply that Thai medicine used P. cablin as a component in formulation to relief fever. The mechanism inhibited the generation of ROS and RNS which associated with anti-inflammatory effects. Likewise chemical assays, the flavonoids would be main active compounds that displayed antioxidant properties. In previous report, the active hydroxyl groups of flavonoid are generally glycosylated. Glycosylation increases hydrophilicity of a molecule, which in its turn impairs its interaction with cellular membranes and decreases its rate of absorption [38, 39]. Moreover, the literature showed flavonoids also effective scavengers of peroxyl, superoxide, and peroxynitrite radicals [40].

The MIC and MBC results of the extracts against $S$. aureus, MRSA, P. aeruginosa, S. pyogenes, and Candida albicans are shown in Table 3. The ethanolic extract ( $5 \mathrm{mg} / \mathrm{disk})$ demonstrated the best activity against MRSA, S. aureus, and S. pyogenes with zone diameters of $11.67 \pm 1.53,10.33 \pm$ 2.52 , and $10.33 \pm 1.15 \mathrm{~mm}$, respectively. The MIC and MBC values ranged from 0.039 to $5 \mathrm{mg} / \mathrm{mL}$ for all bacteria. The ethanolic extracts were the most effective against $S$. pyogenes $(0.039 \mathrm{mg} / \mathrm{mL})$. In earlier report on the antimicrobial activity, Lv et al., 2011, it has been reported that essential oil of $P$. cablin showed moderate antibacterial activity against $S$. aureus, $B$. subtilis, and S. cerevisiae [41].

The antibacterial activities are attributed to patchouli alcohol, $\alpha$-patchoulene (-)-patchouli alcohol, and pogostone that have several modes of action [42]. Yang et al. found that pogostone and (-)-patchouli alcohol show potential against cell wall membranes by molecular docking, and the result proved those chemical compounds have good antibacterial activities by MIC and MBC assay [11].

\section{Conclusion}

We have shown that ethanolic extract from Pogostemon cablin showed moderate antioxidant activity and inhibited bacteria commonly responsible for community and hospital acquired infections. Our results support the ethnotherapeutic claim of Pogostemon cablin. Additional work should be done to exploit these properties to see if these extracts might have a clinical application. 
TABle 3: Antimicrobial activity against five microorganisms of Pogostemon cablin leaves extracts $(n=3)$.

\begin{tabular}{|c|c|c|c|c|c|}
\hline \multirow{2}{*}{ Extract } & \multicolumn{5}{|c|}{ Inhibition zone (mm.), MIC $(\mathrm{mg} / \mathrm{mL}), \mathrm{MBC}(\mathrm{mg} / \mathrm{mL})$} \\
\hline & S. aureus & MRSA & P. aeruginosa & S. pyogenes & C. albicans \\
\hline $\begin{array}{l}\text { Water } \\
\text { (Conc. } 1 \mathrm{mg} / \text { disc) }\end{array}$ & $\begin{array}{c}0^{*} \\
0.625^{\dagger} \\
0.625^{\ddagger}\end{array}$ & $\begin{array}{c}8.33 \pm 1.53 \\
2.5^{\dagger} \\
2.5^{\ddagger}\end{array}$ & $\begin{array}{c}0 \\
1.25^{\dagger} \\
1.25^{\ddagger}\end{array}$ & $\begin{array}{c}0 \\
>5^{\dagger} \\
>5^{\ddagger}\end{array}$ & $\begin{array}{c}0 \\
>5^{\dagger} \\
>5^{\ddagger}\end{array}$ \\
\hline $\begin{array}{l}\text { Ethanol } \\
\text { (Conc. } 5 \mathrm{mg} / \text { disc) }\end{array}$ & $\begin{array}{c}10.33 \pm 2.52^{*} \\
0.625^{\dagger} \\
0.625^{\ddagger}\end{array}$ & $\begin{array}{c}11.67 \pm 1.53^{*} \\
5^{\dagger} \\
5^{\ddagger}\end{array}$ & $\begin{array}{c}0^{*} \\
0.625^{\dagger} \\
0.625^{\ddagger}\end{array}$ & $\begin{array}{c}10.33 \pm 1.15^{*} \\
0.039^{\dagger} \\
0.039^{\ddagger}\end{array}$ & $\begin{array}{c}0^{*} \\
>5^{\dagger} \\
>5^{\ddagger}\end{array}$ \\
\hline $\begin{array}{l}\text { Amoxicillin } \\
\text { (Conc. } 10 \mu \mathrm{g} / \text { disc) }\end{array}$ & NT & NT & NT & $\begin{array}{c}35 \pm 0.00^{*} \\
0.016^{\dagger} \\
0.0256^{\ddagger}\end{array}$ & NT \\
\hline $\begin{array}{l}\text { Gentamycin } \\
\text { (Conc. } 10 \mu \mathrm{g} / \text { disc) }\end{array}$ & $\begin{array}{c}15 \pm 0.00^{*} \\
0.195^{\dagger} \\
0.195^{\ddagger}\end{array}$ & $\begin{array}{c}10 \pm 0.00^{*} \\
>200^{\dagger} \\
>200^{\ddagger}\end{array}$ & $\begin{array}{c}12 \pm 0.00^{*} \\
0.39^{\dagger} \\
0.39^{\ddagger}\end{array}$ & NT & NT \\
\hline
\end{tabular}

* Inhibition zone.

${ }^{\dagger} \mathrm{MIC}$.

${ }^{\ddagger} \mathrm{MBC}$.

\section{Conflicts of Interest}

The authors declare that there are no conflicts of interest regarding the publication of this paper.

\section{Acknowledgments}

The authors thank Dr. Bob Taylor for reviewing the manuscript. This work was supported by Faculty of Medicine and Center of Scientific Equipment for Advanced Research, Thammasat University, providing equipment used for biological assays.

\section{References}

[1] L. Dall and J. F. Stanford, "Fever, chills, and night sweats," in Clinical Methods: The History, Physical, and Laboratory Examinations, Butterworth Publishers, Boston, Mass, USA, 1990.

[2] P. V. Dasaraju and C. Liu, "Infections of the respiratory system," in Medical Microbiology, The University of Texas Medical Branch at Galveston, Galveston, Tex, USA, 1996.

[3] J. W. Peterson, "Bacterial pathogenesis," in Medical Microbiology, The University of Texas Medical Branch at Galveston, Galveston, Tex, USA, 1996.

[4] M. M. Markiewski and J. D. Lambris, "The role of complement in inflammatory diseases from behind the scenes into the spotlight," The American Journal of Pathology, vol. 171, no. 3, pp. 715727, 2007.

[5] A. Cekici, A. Kantarci, H. Hasturk, and T. E. Van Dyke, "Inflammatory and immune pathways in the pathogenesis of periodontal disease," Periodontology 2000, vol. 64, no. 1, pp. 57-80, 2014.

[6] T. Fukai and M. Ushio-Fukai, "Superoxide dismutases: role in redox signaling, vascular function, and diseases," Antioxidants \& Redox Signaling, vol. 15, no. 6, pp. 1583-1606, 2011.

[7] M. Balakrishna, S. S. Kaki, M. S. Karuna, S. Sarada, C. G. Kumar, and R. B. Prasad, "Synthesis and in vitro antioxidant and antimicrobial studies of novel structured phosphatidylcholines with phenolic acids," Food Chemistry, vol. 221, pp. 664-672, 2017.
[8] M. K. Swamy and U. R. Sinniah, "A comprehensive review on the phytochemical constituents and pharmacological activities of Pogostemon cablin Benth. An aromatic medicinal plant of industrial importance," Molecules, vol. 20, no. 5, pp. 8521-8547, 2015.

[9] C. Picheansoonthon and V. Jerawong, Thai Pharmaceutical Textbook No. 5 Materia Medica, Amarin Printing \& Publishing, Bangkok, Thailand, 2001.

[10] S. Tadtong, C. Puengseangdee, S. Prasertthanawut, and T. Hongratanaworakit, "Antimicrobial constituents and effects of blended eucalyptus, rosemary, patchouli, pine, and cajuput essential oils," Natural Product Communications, vol. 11, no. 2, pp. 267-270, 2016.

[11] X. Yang, X. Zhang, S.-P. Yang, and W.-Q. Liu, "Evaluation of the antibacterial activity of patchouli oil," Iranian Journal of Pharmaceutical Research, vol. 12, no. 3, pp. 307-316, 2013.

[12] A. Wei and T. Shibamoto, "Antioxidant activities and volatile constituents of various essential oils," Journal of Agricultural and Food Chemistry, vol. 55, no. 5, pp. 1737-1742, 2007.

[13] H. Kiyohara, C. Ichino, Y. Kawamura, T. Nagai, N. Sato, and H. Yamada, "Patchouli alcohol: in vitro direct anti-influenza virus sesquiterpene in Pogostemon cablin Benth.," Journal of Natural Medicines, vol. 66, no. 1, pp. 55-61, 2012.

[14] S. C. Yoon, I.-G. Je, X. Cui et al., "Anti-allergic and anti-inflammatory effects of aqueous extract of Pogostemon cablin," International Journal of Molecular Medicine, vol. 37, no. 1, pp. 217-224, 2016.

[15] M. Miyazawa, Y. Okuno, S.-I. Nakamura, and H. Kosaka, "Antimutagenic activity of flavonoids from Pogostemon cablin," Journal of Agricultural and Food Chemistry, vol. 48, no. 3, pp. 642-647, 2000.

[16] E.-K. Park, H.-K. Yoon, and D.-H. Kim, "Antithrombotic activity of Sunghyangjunggisan," Natural Product Sciences, vol. 8, no. 2, pp. 71-75, 2002.

[17] Y. Yang, K. Kinoshita, K. Koyama et al., "Anti-emetic principles of Pogostemon cablin (Blanco) Benth," Phytomedicine, vol. 6, no. 2, pp. 89-93, 1999.

[18] J. Yu, Y. Qi, G. Luo, H.-Q. Duan, and J. Zhou, "Extraction and analysis of the essential oil in Pogostemon cablin by enzymatic hydrolysis and inhibitory activity against Hela cell 
proliferation," Journal of Chinese Medicinal Materials, vol. 35, no. 5, pp. 796-799, 2012.

[19] J. B. Jeong, J. Choi, Z. Lou, X. Jiang, and S.-H. Lee, "Patchouli alcohol, an essential oil of Pogostemon cablin, exhibits antitumorigenic activity in human colorectal cancer cells," International Immunopharmacology, vol. 16, no. 2, pp. 184-190, 2013.

[20] O. Folin and V. Ciocalteu, "On tyrosine and tryptophane determinations in proteins," The Journal of Biological Chemistry, vol. 73, pp. 627-650, 1927.

[21] B. Mayur, S. Sandesh, S. Shruti, and S. Sung-Yum, "Antioxidant and alpha-glucosidase inhibitory properties of Carpesium abrotanoides L.," Journal of Medicinal Plants Research, vol. 4, pp. 1547-1553, 2010.

[22] K. Yamazaki, A. Hashimoto, Y. Kokusenya, T. Miyamoto, and T. Sato, "Electrochemical method for estimating the antioxidative effect of methanol extracts of crude drugs," Chemical and Pharmaceutical Bulletin, vol. 42, pp. 1663-1665, 1994.

[23] R. Re, N. Pellegrini, A. Proteggente, A. Pannala, M. Yang, and C. Rice-Evans, "Antioxidant activity applying an improved ABTS radical cation decolorization assay," Free Radical Biology and Medicine, vol. 26, no. 9-10, pp. 1231-1237, 1999.

[24] S. Tewtrakul and A. Itharat, "Nitric oxide inhibitory substances from the rhizomes of Dioscorea membranacea," Journal of Ethnopharmacology, vol. 109, no. 3, pp. 412-416, 2007.

[25] W. Surarit, C. Jansom, N. Lerdvuthisopon, S. Kongkham, and P. Hansakul, "Evaluation of antioxidant activities and phenolic subtype contents of ethanolic bran extracts of Thai pigmented rice varieties through chemical and cellular assays," International Journal of Food Science and Technology, vol. 50, no. 4, pp. 990-998, 2015.

[26] V. Lorian, Antibiotics in Laboratory Medicine, Williamsons \& Wilkins, Baltimore, Md, USA, 3rd edition, 1996.

[27] S. D. Sarker, L. Nahar, and Y. Kumarasamy, "Microtitre platebased antibacterial assay incorporating resazurin as an indicator of cell growth, and its application in the in vitro antibacterial screening of phytochemicals," Methods, vol. 42, no. 4, pp. 321324, 2007.

[28] M. T. Yilmaz, "Minimum inhibitory and minimum bactericidal concentrations of boron compounds against several bacterial strains," Turkish Journal of Medical Sciences, vol. 42, supplement 2, pp. 1423-1429, 2012.

[29] S. B. Iloki-Assanga, L. M. Lewis-Luján, C. L. Lara-Espinoza et al., "Solvent effects on phytochemical constituent profiles and antioxidant activities, using four different extraction formulations for analysis of Bucida buceras L. and Phoradendron californicum," BMC Research Notes, vol. 8, article 396, 2015.

[30] A. Munin and F. Edwards-Lévy, "Encapsulation of natural polyphenolic compounds; a review," Pharmaceutics, vol. 3, no. 4, pp. 793-829, 2011.

[31] R. Murugan and T. Parimelazhagan, "Comparative evaluation of different extraction methods for antioxidant and antiinflammatory properties from Osbeckia parvifolia Arn.- an in vitro approach," Journal of King Saud University-Science, vol. 26, no. 4, pp. 267-275, 2014.

[32] B. S. Bhau, B. Borah, R. Ahmed et al., "Influence of rootknot nematode infestation on antioxidant enzymes, chlorophyll content and growth in Pogostemon cablin (Blanco) Benth.," Indian Journal of Experimental Biology, vol. 54, no. 4, pp. 254261, 2016.

[33] K. Tang, M. Li, S. Dong, Y.-Q. Li, J.-W. Huang, and L.-M. Li, "Allelopathy autotoxicity effects of aquatic extracts from rhizospheric soil on rooting and growth of stem cuttings in
Pogostemon cablin," Journal of Chinese Medicinal Materials, vol. 37, no. 6, pp. 935-939, 2014.

[34] Q. Guo, Y. Wu, Y. Lin, and H. Zheng, "Effect of $\mathrm{NaCl}$ stress on growth and antioxidant systems of Pogostemon cablin," Zhongguo Zhongyao Zazhi, vol. 34, no. 5, pp. 530-534, 2009.

[35] Y. Xu, Y.-G. Wu, Y. Chen et al., "Autotoxicity in Pogostemon cablin and their allelochemicals," Revista Brasileira de Farmacognosia, vol. 25, no. 2, pp. 117-123, 2015.

[36] S. A. Baba and S. A. Malik, "Determination of total phenolic and flavonoid content, antimicrobial and antioxidant activity of a root extract of Arisaema jacquemontii Blume," Journal of Taibah University for Science, vol. 9, no. 4, pp. 449-454, 2015.

[37] S. Kumar and A. K. Pandey, "Chemistry and biological activities of flavonoids: an overview," The Scientific World Journal, vol. 2013, Article ID 162750, 16 pages, 2013.

[38] C. F. F. Grael, A. Kanashiro, L. M. Kabeya et al., "In vitro study of antioxidant and scavenger properties of phenolic compounds from Lychnophora species," Química Nova, vol. 33, no. 4, pp. 867-870, 2010.

[39] C. L. Bowe, L. Mokhtarzadeh, P. Venkatesan et al., "Design of compounds that increase the absorption of polar molecules," Proceedings of the National Academy of Sciences of the United States of America, vol. 94, no. 22, pp. 12218-12223, 1997.

[40] K. E. Heim, A. R. Tagliaferro, and D. J. Bobilya, "Flavonoid antioxidants: chemistry, metabolism and structure-activity relationships," The Journal of Nutritional Biochemistry, vol. 13, no. 10, pp. 572-584, 2002.

[41] F. Lv, H. Liang, Q. Yuan, and C. Li, "In vitro antimicrobial effects and mechanism of action of selected plant essential oil combinations against four food-related microorganisms," Food Research International, vol. 44, no. 9, pp. 3057-3064, 2011.

[42] K. H. Kim, C. Beemelmanns, J. Clardy, and S. Cao, "A new antibacterial octaketide and cytotoxic phenylethanoid glycosides from Pogostemon cablin (Blanco) Benth," Bioorganic and Medicinal Chemistry Letters, vol. 25, no. 14, pp. 2834-2836, 2015. 

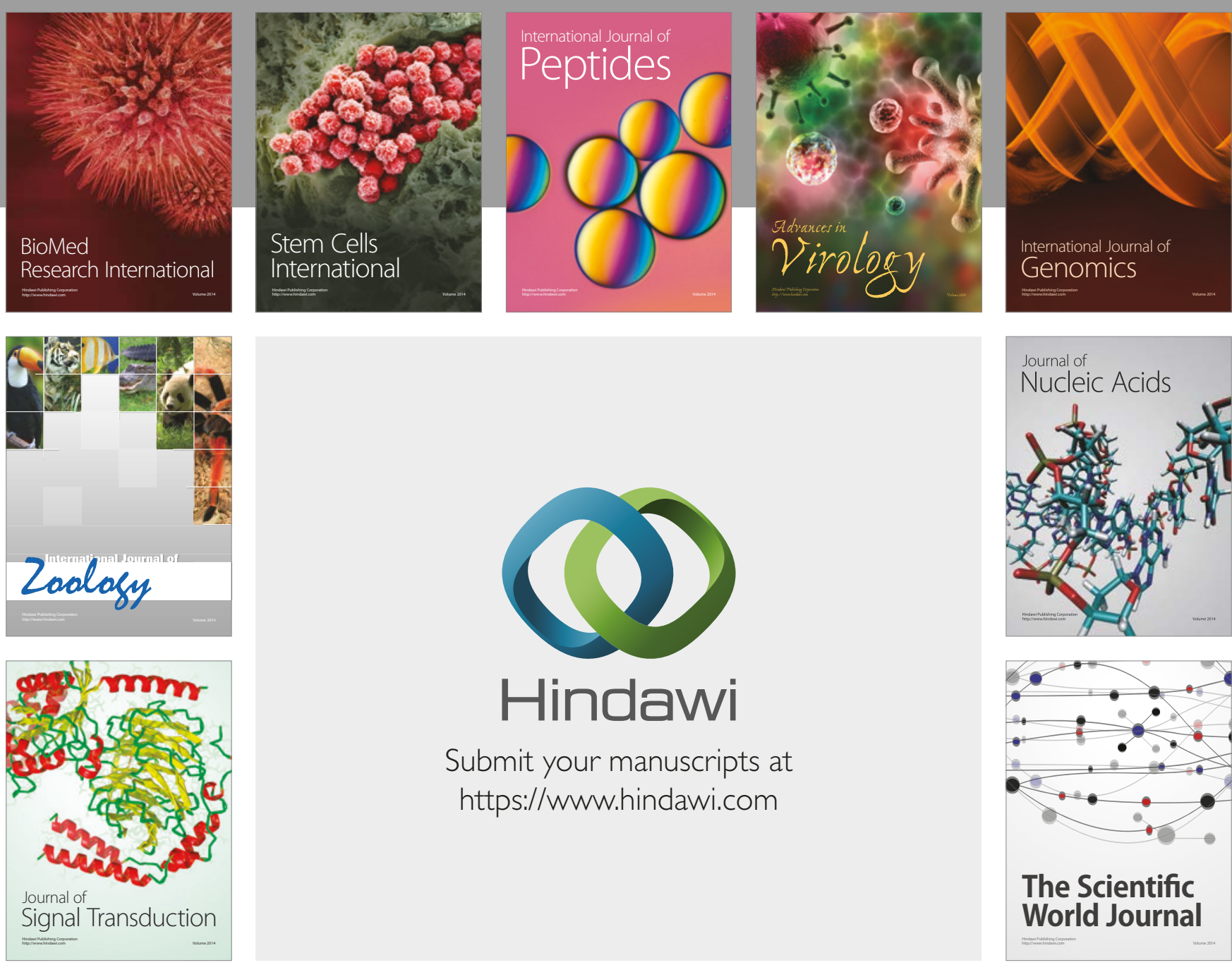

Submit your manuscripts at

https://www.hindawi.com
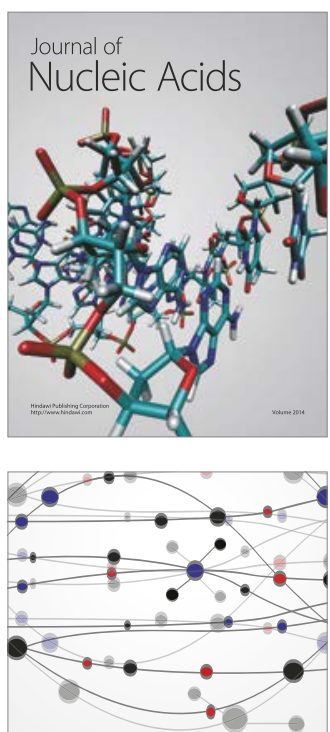

The Scientific World Journal

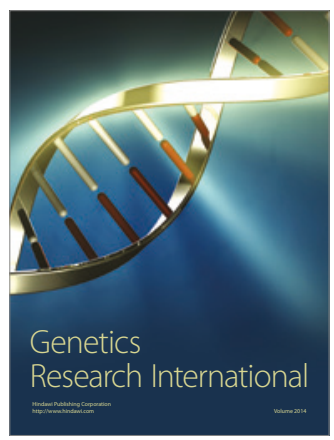

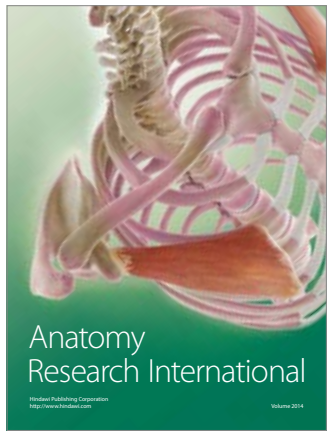

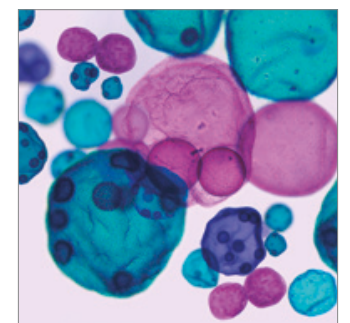

International Journal of Microbiology
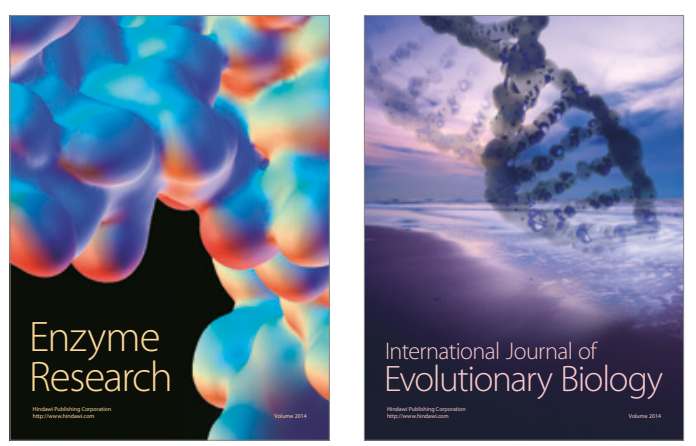
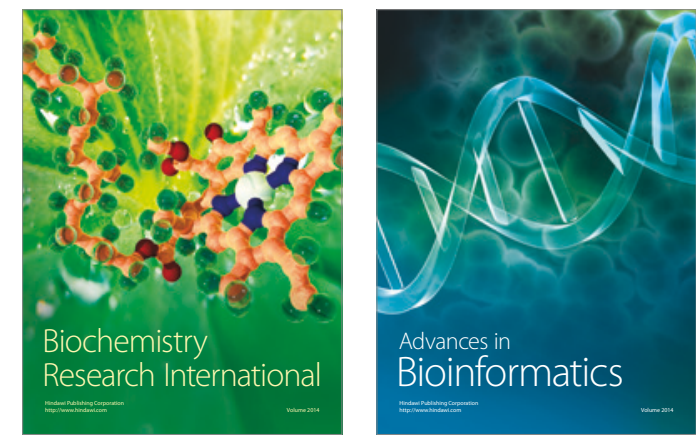

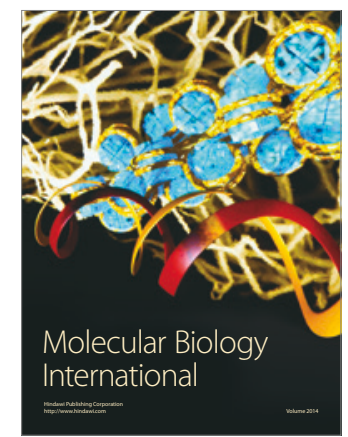

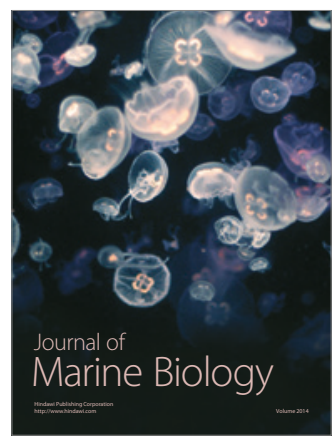

